$\mathrm{PhD}$ in Pedagogical Sciences, Instructor, YULIIA STEPURA

Volodymyr Korolenko Poltava National Pedagogical University Address: 2 Ostrohradskyi St., Poltava, 36003, Ukraine

E-mail: stepurochka@gmail.com

\title{
FOREIGN EXPERIENCE IN USING EDUCATIONAL LOGOTHERAPY IN PROFESSIONAL ACTIVITIES OF PRIMARY SCHOOL TEACHERS
}

\begin{abstract}
The article examines the nature and importance of using aesthetic and therapeutic concept and educational logotherapy, in particular, for creating a special emotionally comfortable socioeducational environment for primary education. The author has represented interpretation of foreign scholars' views (J. Bugental, V. Frankl, A. Maslow, R. May, J. Moreno, C. Rogers et al.) on such terms as "communication", "aesthetotherapy", "educational logotherapy" etc. An attempt has been made to analyze the social content of pedagogical activity in the context of using logotherapy in primary school based on an agogical paradigm. In the scope of the article, the specific of using the therapeutic metaphor in the educational environment of primary school has been represented as well as the basic stages of its implementation have been determined. These stages are the following: description of the storyline, persuasion and binding. The author has defined the role of the "living metaphors" in organization of the therapeutic interaction between the teacher and primary schoolchildren. Particular attention has been paid to formation of the humanistic competency among primary schoolchildren; this competency is to be based on their understanding of the following philosophical and pedagogical categories: a norm (as a means and a results of pupils' social activity), freedom (as a mean and a result of individual self-expression among primary schoolchildren) and happiness (as an individual self-expression among primary schoolchildren). The author has assessed the role of deflection method and paradoxical intention for the social development of the pupil and further formation of the individual. Additional attention has been paid to determination of the socioeducational and psychological and pedagogical potential of such leading method in logotherapy as "The Socratic dialogue" (or "The Socratic circle"); as well have been highlighted the main stages of its implementation: consent (search for what pupil may agree), doubt (an expression of doubts towards weak arguments of interlocutor) and arguments (the teacher must convey one's opinion, without any resistance from the child); have been represented different various algorithms of its realization: the method of "aquarium", "panel method" and "questioning technique".
\end{abstract}

Keywords: agogics, aesthetotherapy, logotherapy, primary school age, pedagogical communication, "The Socratic dialogue", social education, therapeutic metaphor.

\section{INTRODUCTION}

Primary school age is an important stage in the process of development of each particular individual as this age is sensitive for successful sociopsychological, physical, moral and spiritual health. In this regard, the prior task of primary school is to create conditions for fulfillment of needs and interests of pupils, determination of their talents and life and preferences, harmonization of interpersonal relations in the context of the education 
process, formation of the necessary range of knowledge, skills and competencies as well as practical implementation of educational support in the process of addressing the moral, spiritual, personal and social problems. An important role in the realization of these objectives belongs to the teacher, who is the subject of the education process and, at the same time, manages the set of following tasks: being an agent for pupils' socialization; managing the educational relations; shaping the opinions and beliefs of schoolchildren; providing a range of measures, needed for the child's social welfare in the process of education. The use of the aesthetic and therapeutic concept is an effective mean for the addressing the tasks, as it is "a new method of teaching and training for a body, soul, emotions, mind and willpower of man" (Kyiashchenko, 1998, p. 185) and a powerful tool for managing the "authoritarian and soulless educational practice, leading to a condition of social apathy among pupils, school aggression, "inhumane" behaviour in relations between the teacher and the pupil and mental imbalance in own worldview" (Fedii, 2012).

\section{THE AIM OF THE STUDY}

The aim of the study is to reveal the psychological, educational and social potential of pedagogical logotherapy and to highlight the specific of its use in primary school.

THEORETICAL FRAMEWORK AND RESEARCH METHODS

In modern scientific works the problem of using pedagogical logotherapy in professional activity has been studied mainly through the prism of philosophical, psychotherapeutic and man-centered approaches, which fully covers the content of its aesthetic and theraupeutic nature (Fedii, 2012).

This article is a scientific and methodological research, during which were used the methods of analysis, synthesis, comparison and synthesis of scholarly works of native (O. Fedii, A. Makarenko, V. Sukhomlynskyi, I. Ziaziun et al.) and foreign scientists (J. Bugental, V. Frankl, A. Maslow, R. May, J. Moreno, C. Rogers et al.).

\section{RESULTS}

The aesthetic and therapeutic concept contains a huge arsenal of up-to-date means of influence on the personality of modern pupils (picture, photography, music, game, communication, fairytale, nature, etc.). Still, regardless of the historical period, the leading instrument of persuasion, promotion, organization and education of schoolchildren is communication. The importance of communication in teaching activities is represented in the scientific works of J. Bugental, V. Frankl, A. Makarenko, A. Maslow, R. May, J. Moreno, C. Rogers, V. Sukhomlynskyi, I. Ziaziun et al.

A significant number of the scholars note that pedagogical communication is a form of social therapy and, at the same time, a powerful method of "treatment" of pupils" behaviour. For instance, I. Ziaziun (2002) stated that professional pedagogical communication is an organic system of social and psychological interaction between the teacher and pupils. The major essence of such communication is represented in the form of informational exchange, implementation of educational influence, organization of relationship by using the means of communication. Moreover, the teacher acts as an activator of this process: they organize and, furthermore, manage it.

V. Sukhomlynskyi (1988) noted that "every word, that sounds in school, should be thoughtful, wise and purposeful - and it is especially important - the word should appeal to conscience of the individual human, with whom we deal ... to omit the words' depreciation and to maximize the value of the word" (p. 140). Therefore, pedagogical communication should be a special kind of creativity that focuses on the development of students' emotional 
sphere, formation of their active life position, internal motivation for learning, happiness from gaining knowledge and desire for achievement of success in all areas of life. In this context, attempting the aesthetic and therapeutic influence on pupils, the teacher works as a psychotherapist (to some extent), who provides a kind of social and psychosocial support in the process of addressing a variety of academic and personal problems (such as loss of interest in education, social exclusion, anxiety, inability to build interpersonal interaction, etc.).

One of the leading means of the practical implementation of the above listed functions by the primary school teacher is pedagogical logotherapy (one of the various types of social therapy) (from Greek "logos" - meaning), which is a type aesthetotherapy, aimed at providing the individual with the meaning of life, redirecting their attention to the moral and cultural values of personality (Fedii, 2012).

This psychotherapeutic direction was introduced into scientific world by V. Frankl (1990), who emphasized that "the desire for meaning" is a natural driving force of behaviour and personal development regardless of sex, age or status in society.

The leading idea of pedagogical logotherapy is the humanistic idea of education and development of personality, who, according to J. Bugental (2010), should be prepared for internal comprehension of events and for making choice of adherents in amore conscious way and as an outcome, for being more sincere with them.

Another scholar R. May (2001) argued that the main purpose of logotherapy is to help people in comprehending the depths of their personality that has a specific structure: freedom (in self-expression, communication, etc.), personality (as a result of its internal "search"), social integration ("it is not possible to understand human without one's social environment") and "spiritual strength", which provides the individual with an option of taking and making sustainable natural spiritual tension in an adequate manner.

Thus, the main purpose of pedagogical communication in the context of logotherapy is not only management and coordination of the education process, but also, revelation of the essential powers and capabilities of pupils, provision of the experience needed for feeling happy because of making independent decisions and solving vital problems.

The necessity for social and content fulfillment of pedagogical activities in the context of the practical application of logotherapy in primary school is reflected in the innovative scientific direction - agogics (Greek "agoge" - transaction, education), - the theory and practice of human perfection: one's skills, knowledge and art of happy life in the process and final outcomes of education and development (Bim-Bad, 2010). While referring to the statements of the author of this scientific concept, it is possible to make a claim that pedagogical activity, particularly in primary school, is agogics in its essence, because it involves the process of bringing up" a young generation (primary pupils, in particular), by improving their life skills and knowledge in accordance with the established social norms.

The efficiency of this process is determined by the development of pupils' humanistic competency, which is defined by such philosophical categories as norms (as a means and a results of pupils' social activity), freedom (as a mean and a result of individual selfexpression among primary schoolchildren) and happiness, which is an outcome of pupils' education and development. According to B. Bim-Bad (2010), "a norm is a core of being and knowledge" (p. 6), the main mechanism of child's assimilation of "the rules of life", which develops a kind of "educational and social intellect", which, in turn, helps them to enter the educational environment in an optimal manner and, furthermore, shape their own social status in a comparatively independent way. In the process of communication with pupils, the teacher refers to specific (social, cultural, ethical, educational etc.) norms, which determine the level of pupils' education and their ability to match these norms. 
In addition to the need of matching the existing norms and standards by the pupils, the main task of the teacher in the context of logotherapy is to develop schoolchildren's sense of personal and psychological comfort, which is often called happiness. Quite right is the opinion of M. Argyle (2003), who noted that a person reaches a happy self-awareness through communicating with spiritually close people (parents, friends, teachers, etc.), in other words, by reaching the unity with micro- and macro-society.

From the perspective of current investigation, this interpretation of happiness is the key in professional communication of primary school teachers, because in the period of primary school age, pupils need a special support and understanding of the one's closest environment. Close to the definition of "happiness" or "psychological comfort", according to opinion of O. Fedii (2012), is the concept of "freedom", which is a condition of harmonization of human relationships with one's environment.

Therefore, it is a complicated task to overestimate the necessity of practical implementation of the pedagogical logotherapy into the educational environment of primary school, because it helps to form the 'happy view of the world' among pupils. Such worldview is an outcome of the proper balancing of such philosophical and pedagogical categories as a norm and freedom, and the main educational slogan in this case should be the following - "formation of a free creative personality that is able to be oneself and feel one's own "self" (Fedii, 2012, p. 27).

One of the leading means of optimization of the professional pedagogical activity in the context of logotherapy is the therapeutic metaphor, which, as noticed by J. Mills and R. Crowley (2000), is launched through three major stages: plot, persuasion and binding. Thus, it is essential to give a brief characteristic of its psychological, pedagogical, social and educational potential.

The plot should gradually unfold in the following stages: conflict (must match the nature of the pupils' problems), description of the characters (to some extent has to implement unconscious images of schoolchildren), playback of the problematic educational situations (which were taken care of), crisis (as a transitional point in decision-making), self-understanding among pupils in their new role as the culmination and celebration of their personal development. Creation of the therapeutic stories in accordance with the corresponding scheme is done by using especially fictional themes, fairy-tale motifs, popular animated themes, imagination of pupils, cases of life of the teacher and others.

The persuasion should organically fit into the context of the therapeutic metaphor. On the conscious level, pupils take it as part of the story (not correlating it with themselves), but the subconscious mind of pupils will be looking for these convictions and perceive them as a motivator for some actions. As a result of this activity, by changing the "literary tones", the favourable conditions for identification of the needed behavioural resources of schoolchildren (which have not been used before) are created.

The binding must be supplemented with sensory characteristics of teachers' speech, which promotes awakening all sensor systems among pupils simultaneously. At this stage, pupils have the opportunity to identify the source of internal resources and direct them to the problematic area (Mills \& Crowley, 2000).

One of the leading roles in the process of organizing the logotherapy interaction in primary school belongs to "live metaphors", which, in turn, are the set of the home tasks, represented in the metaphorical form and oriented toward reproduction of the effective algorithm for solving pupils' problems and are excellent curative and educational addition to the therapeutic narrative. 
For example, for the schoolchildren who used to interfere with others, it is possible to think out a metaphor, associated with the hedgehog that protects itself with spines, and thus does not provide others with the possibility of understanding its sensitive soul. In the form of a "living metaphor", it is possible to give a following task for a pupil: they must find the hedgehog in the village or in other place (such as park, near their own house, in the cottage, near school, etc.), make an attempt of following them and, furthermore, attract in a gently, patiently and gradually way and, as a result, to feed and domesticate it.

The author of logotherapy V. Frankl (1990) actualized the value of the following methods of social changing personality:

1.Direflection method, which promotes minimization of excessive self-control among pupils, which, in turn, is related to considerations about their shortcomings and complexes and, thus, prevents them from the full and complex social life.

2. The paradoxical intention method implies that the teacher should encourage schoolchildren to those activities, which are omitted by them (because of some fears, complexes, uncomfortable or traumatic situations, etc.). In this case, the teacher uses different kinds of humour. For example, if the child feels fear of enclosed spaces, one is offered to make oneself to spend a durable timeframe in such a room, while being supported with several funny stories and humoresques. During the implementation of this method, the major part of pupils' fears disappears and pupils acquire self-confidence, and are no longer afraid of what was previously avoided by one because of fears and frustrations.

3. "The Socratic dialogue" is one more method of logotherapy, which implies involvement of pupils into cooperation and expansion of their consciousness. "The Socratic dialogue" is a kind of intellectual duel between the teacher and the child, during which inconsistent, contradictory and unsubstantiated judgments of pupils are adjusted. The teacher "leads" the child to the planned conclusion, logically arguing their position. During the conversation, the teacher formulates the question to give the child the maximal number of positive responses (Frankl, 1990). This method enhances pupils' thinking, concentration of their attention, shapes an adequate assessment of the current debate by pupils and their role in it. Typically, the "The Socratic dialogue" consists of three phases: consent (search for what pupil may agree with), doubt (an expression of doubts towards weak arguments of the interlocutor) and arguments (the teacher must convey their opinion, without any resistance from the child). The result of such an intellectual battle is expressed in three forms: the pupil wishes the same things as the teacher, the schoolchild adequately proclaims their own point of view, the child finds out the most effective approach towards teacher's argumentation. "The Socratic circle" ("The Socrates Seminar") is one of the forms of "Socratic dialogue". It is a pedagogical approach, based on "The Socratic dialogue" and applied into the practice for better absorption of the information by pupils (Metod Sokrata, 2016). This technique implies gaining specific knowledge through the discussions and is based on the opinion that the pupil has some ideas on the topic of discussion, while the new knowledge is gained through the discussion. This method is based on the belief that schoolchildren would get deeper understanding of the essence of the subject with thoughtful arguments rather than via the means of usual familiarization with the material. There are different variations of "The Socratic circle":

- "Aquarium": pupils form two circles external (an observer) and internal (active members) together with their teacher. Members of the inner circle are involved in the discussion of the issue, offered by the teacher. Others watch and act when any of offered versions interests them; they supplement, ask questions, concretize. In this case, the "observer" should stand near an active participant (the one, who has attracted their attention 
with an offered version). After discussing a problem participants change their roles (those, who were outside of the circle, seat into a circle);

- "Panel method": pupils are divided into groups of six to eight and form a circle. Members of each group select a representative or a chief, who will defend their position in the process of discussion. Within the timeframe of 15-20 minutes, the group is engaged into the process of discussion and generation of a common point of view. Representatives of the groups are gathered in the center of the circle and express the position of their group and defend it, while other pupils watch the progress of those discussions and assess the way the representative of the group expresses their common position. The schoolchildren cannot express their opinion; they are provided with the option of sending notes during the discussion, where their arguments are clearly represented;

- "Questioning technique": the pupils' interaction is based on a question- answer system, which provides the teacher with an option of effective assessment and evaluation of the depth of pupils' thought. Questions are focused on general ideas rather than on specific information and usually begin with guiding statements. This strategy helps participants in concentrating on their problem and producing the wide set of different perspectives of its resolution. Even more, they have to express their opinion, based on the statements of previous speakers (Metod Sokrata, 2016).

The methods and techniques of logotherapy outlined above intensify thinking, attention, communicative competence and creativity of primary schoolchildren. In addition, these methods enhance children's self-development and self-determination, inspire them to seek new achievements in education and life, help in terms of independent formation of their own social position and outlook. Finally, the children learn to express their opinions and arguments and defend them.

\section{CONCLUSIONS}

Social and creative nature of pedagogical logotherapy proves its humanistic orientation and formative character. Based on analysis of scientific sources, it is essential to note that using different techniques of logotherapy in primary school contributes to forming a "value field". This 'value field', in turn, is a synthesis of the interaction of such philosophical concepts of freedom, norms and happiness, which integrate the value of creation (are top-priority and based on the common work of pupils), the value of experience (e.g., friendship, love, etc.) and the value of the relation (the conscious attitude of pupils toward the objective reality).

Prospects for further researches should determine the development of the algorithm and methodical support for the process of implementation of the elements of pedagogical logotherapy in the educational environment of primary school, that may serve as a fertile background for creation of a positive emotional and comfortable atmosphere of sympathy understanding, mutual trust, empathy communication and actively social mutual creativity.

\section{REFERENCES}

1. Argyle, M. (2003). Psikhologiya schastya. Sankt-Peterburg: Piter.

2. Bim-Bad, B. M. (2010). Kategorii sovremennykh nauk o vospitanii. Moskva; Voronezh: Rossiyskaya akademiya obrazovaniya, Moskovskiy psikhologo-sotsialnyiy institut.

3. Bugental, G. (2001). Iskusstvo psihoterapevta. Sankt-Peterburg: Piter.

4. Fedii, O. A. (2012). Estetoterapiia. Kyiv: Tsentr uchbovoi literatury. 
5. Frankl, V. (1990). Chelovek v poiskah smyisla. Moskva: Progress.

6. Kiyaschenko, N. I. (1998). Sovremennyie kontseptsii esteticheskogo vospitaniya. Moskva: Ifran.

7. May, R. (2001). Iskusstvo psihologicheskogo konsultirovaniya. Moskva: Nezavisimaya firma "Klass".

8. Metod Sokrata. (2016). Retrieved from https://ru.wikipedia.org.

9. Mills, J, \& Crowley, R. (2000). Terapevticheskie metaforyi dlya detey $i$ "vnutrennego rebenka". Moskva: Nezavisimaya firma "Klass".

10. Sukhomlynskyi, V. O. (1988). Sto porad uchyteliu. Kyiv: Radianska shkola.

11. Ziaziun, I. A. (2002). Pedahohichna maisternist. Kyiv: SPD Bogdanova A. M. 